\title{
LETTERS FROM READERS
}

My doctoral dissertation (De Westindische plantages van 1720 tot 1795; financiën en handel, Nijmegen, 1973, 367 pp., bibliography, tables, charts) was privately published at the time of my defense. Very few copies were printed but the book was available through normal trade channels for a few years until it went out of print. Since there now seems to be a growing interest in the work, I am prepared to have a reprint produced, provided at least 150 copies can be sold. The book would then cost 50 to 60 guilders, excluding postage and packing.

Those interested in this work are requested to write me. Notice will be given in a future Itinerario regarding the decision to reprint and, if the response is positive, when the book will again be available. (Most likely at the end of this year or beginning of 1983.)

J.P. van der Voort

Amalia van Solmslaan 6

3136 CD VLAARDINGEN

The Netherlands

IN MEMORIAM. W. PH. COOLHAAS

Died on 12 April 1981, after a long illness

Willem Philippus Coolhaas, a former official of the Binnenlands Bestuur in the Netherlands Indies and emeritus Professor in the History of the Relations between The Netherlands and Other West European Countries with the overseas world, has died in Bilthoven at the age of 82 . His sickness did not prevent him from remaining active till the end in the field in which he had won most renown, namely colonial history. With the publication of the Generale Missiven of the Dutch East India Company, Coolhaas made available a series of historical sources which will remain essential for the study of Asian history in the seventeenth and eighteenth centuries. Even so, Coolhaas 